Journal of Engineering Sciences, Assiut University, Vol. 37, No. 2, pp. 303-318, March 2009.

\title{
AN EXPERIMENTAL STUDY TO PROTECT STEEL REINFORCING BARS FROM CORROSION
}

\author{
Sayed, A. E. and Mohamed R. A. S.
}

Associate Professors, Civil Engineering Department, Faculty of

Engineering, El-Minia University, El-Minia, Egypt

(Received February 18, 2009 Accepted March 18, 2009)

Steel is an essential part of reinforcing concrete and the corrosion of steel is identified as single largest factor responsible for its deterioration. The alkalinity of concrete, which protects the steel, may be affected by carbonation of the concrete, or by ingress of chloride ions. These may arise from sea salts or environmental corrosives. The corrosion of steel in concrete leads to cracking and eventual spalling of concrete because the rust product has a greater volume than the steel and hence exerts considerable pressure on concrete which eventually leads to its disintegration.

Since the 1970s, research projects and field studies have been conducted on different methods for protecting steel reinforcing in concrete constructions from corrosion damage. These methods include rebar coatings, concrete coatings, use of admixtures, methods for decreasing permeability, increasing concrete cover, cathodic protection, electrochemical method to remove chloride, and corrosion inhibitors.

The purpose of this research is to implement three different protection methods on the reinforcing steel bars to prevent or minimize the occurrence of corrosion as well as to detect the most effective method in the protection technology of steel bars. The parameters studied in this research are the corrosion rate and percentage of chloride. The three protection methods are, coating the steel bars before embedding them in concrete using two different epoxy coating materials as well as using sodium nitrite (by $1 \%$ of cement content) to be added to the concrete mix to work as a corrosion inhibitor. Pullout tests have been carried out and their results are discussed to determine the effect of the implemented different methods for protecting steel from corrosion on the bond strength. The results indicated that the sodium nitrite give the best results as an anticorrosive material, adding 1\% to concrete mix increases the pull-out load by value of $300 \%$ but the epoxy coating materials produced an increase in pull-out load by values $215 \%$ and $240 \%$ increase with the two Epoxy coating materials. Three reinforced concrete full-scale beams protected from corrosion along with a control beam were tested under flexure to study the effect of the applied corrosion protection methods on the mechanical behavior of R.C beams.

KEYWORDS: Sodium nitrite, corrosion protection, epoxy-coated, reinforcement corrosion inhibitor. 


\section{INTRODUCTION}

Corrosion of reinforcing steel bars is considered the most critical factor affecting the durability of concrete structures. Once the reinforcing bars start corroding inside the concrete, it is difficult to stop the process of corrosion progressing and hence the safety, load capacity and design life of the structure are significantly reduced with time. Previously, several investigations have been performed to study various techniques for protecting the reinforcing bars against corrosion and their effect on bond strength between the reinforcing bars and concrete [1-4].

There are many different corrosion protection methods for reinforcing steel in concrete that can be classified as barriers. Some of these methods are to prevent chloride ions from penetrating into the concrete and depassivating the reinforcement. Others work by reducing the movement of air and moisture into the concrete and therefore slowing the corrosion process. Procedures such as using good quality concrete, low water/cement (w/c) ratio and adequate cover have become standard in reinforced concrete construction. Sealers such as placing low-permeability concrete overlays or waterproof membranes with asphalt overlays used on bridge decks and structures in an attempt to keep water and chloride ions from penetrating the concrete.

A corrosion inhibitor is defined as a substance that will prevent or minimize corrosion. Corrosion inhibitors are chemicals that can slow down or prevent corrosion of reinforcing steel in concrete. Corrosion inhibitors were first investigated in the 1960 's. Some early inhibitors included sodium nitrite and either sodium or potassium salts of chromate and benzoate. Research studies concluded that the sodium and potassium salts reduce the strength of the concrete and produce a protection against corrosion inhibition. However, other inhibitors have shown promise as methods for protecting reinforced concrete from corrosion damage. A common inhibitor used today, calcium nitrite, was developed to be used in concrete as a non corrosive set accelerator $[5,6,7,8]$.

Corrosion inhibiting admixtures are unique among the methods to protect reinforced concrete from corrosion damage due to the fact that their protection mechanism becomes an integral part of the concrete matrix. Most inhibitors act by chemically stabilizing the steel surface, although some also act to reduce the permeability of the concrete. Corrosion inhibitors are generally used as admixtures in concrete for new construction, but they can also be used for repairs by being admixed into concrete for patches, sprayed or painted onto the surface of the concrete or applied by saturation treatment $[7,8,9]$.

Epoxy-coated steel, along with higher quality concrete and deeper cover, have provided effective protection against corrosion distress in bridges in the Unites States and Canada for more than a decade. Many investigators are of the opinion that epoxycoated steel is a viable option for long-term protection of reinforced concrete structures. In their opinion, reports of problems with epoxy-coated reinforcement are isolated, and each problem is caused by some shortcoming in the specific materials or construction in the particular structure. However, recently, several investigators have been led to question the use of epoxy-coated reinforcement as a realistic strategy for preventing corrosion damage to concrete structures. These analysts believe that the failures of epoxy-coated steel in structures are indicative of generic shortcomings in the 
technology, and that additional problems will develop as structures continue to age [7, $10,11]$.

As the use of epoxy-coated reinforcement increased, some problems were revealed, such as cracking of the coating during bending and damage to the coating during shipping and handling on the job site. New methods, such as bending the bars before coating, increasing the number of supports during shipping, padding the bundles, and using nylon slings for loading and unloading, were developed in an attempt to overcome these problems [7]. Specifications also started to require plastic or epoxy-coated chairs and tie wires when they were in contact with the epoxy-coated reinforcement to minimize stray currents and to avoid the creation electrical couples within the structure [11].

\section{EXPERIMENTAL WORK}

The Experimental work in this research was directed towards the study of the efficiency of applying different anti-corrosive techniques to protect reinforcing steel bars against corrosion. The Experimental program was divided into three categories. The first category was chosen to carry out some preliminary tests to induce a noticeable corrosion in embedded steel bars in concrete. Three different concrete mixes were used to cast 54 concrete cylinders $(\mathrm{D}=15 \mathrm{~cm}$ and $\mathrm{H}=30 \mathrm{~cm})$ and 27 cubes $(15 \times 15 \times 15 \mathrm{~cm})$ divided into three groups. Each group consists of 18 concrete cylinders and nine cubes. Each cylinder contained one central $(10 \mathrm{~mm}$ diameter) high tensile steel bar embedded in it.

It is of interest to mention that, before casting the specimens, the reinforcing bars were cleaned by a pickling solution composed of $10 \%$ hydrochloric acid as an inhibitor then, rinsed with water and dried. The bar was cleaned by another solution composed of $1 \%$ sodium carbonate. After another rinse with water, the bar was again dried. The purpose of that cleaning for every bar was to insure that the outer surface was completely free from any rust. The bar diameter was measured at ten different locations of the embedded length, to the nearest $0.05 \mathrm{~mm}$, and immediately placed in the casting mould. The bar protruded $25 \mathrm{~cm}$ from only one side of the cylinder. In all mixes, the same type and amount of sand, gravel, cement content and water/cement ratio were used. Complete details of all concrete mixes are given in table (1).

A natural siliceous sand and gravel from El-Minia quarries were used as a fine and coarse aggregates, along with water-cement ratio of 0.45 . The physical and mechanical properties of sand and gravel are given in table (2). Ordinary Portland cement is used in all concrete mix with $350 \mathrm{Kg} / \mathrm{m} 3$ as cement content. The mechanical properties of the used cement are given in Table (3). The mixing operation was carried out in accordance to ASTM C (192-81). Before casting directly, the internal surfaces of the moulds were coated with a thin layer of mineral oil to avoid the development of bond between the mould and the concrete.

All the concrete specimens were casted and compacted according to the Egyptian Standard Specifications (ESS). Specimens were demoulded after 24 hours, and then, cured in water tank for 14 days. They were left in the laboratory condition till the date of testing. All concrete cylinders were tested at 28 days of age. Each cylindrical concrete was put in an electric circuit as shown in fig (1) under a constant 
voltage of $12 \mathrm{~V}$. The exposure of cylinders to the DC electric current continued for a period of $0.0,1.0,2.0,4.0,6.0,8.0$ and 14 days. Three specimens from each group were tested for the same duration of the electric current to get the accurate average reduction of area of steel bars due to corrosion exposure. The concrete cubes tested after 7, 28 and 56 days to find out the compressive strength of the three different concrete mixes after certain ages.

Table(1): Details of concrete mixes for 1 cubic meter.

\begin{tabular}{|c|c|c|c|c|c|c|}
\hline \multirow{2}{*}{$\begin{array}{c}\text { Mix } \\
\text { No. }\end{array}$} & \multicolumn{4}{|c|}{ Mix proportions } & $\begin{array}{c}\text { \% of } \mathrm{CaCl} 2 \text { by } \\
\text { weight of cement }\end{array}$ & $\begin{array}{c}\text { \% of } \mathrm{NaNO} 2 \text { by } \\
\text { weight of cement }\end{array}$ \\
\cline { 2 - 5 } & $\mathrm{C}$ & $\mathrm{S} / \mathrm{C}$ & $\mathrm{G} / \mathrm{C}$ & w/c & & 0.0 \\
\hline 1 & 1 & 1.72 & 3.43 & 0.45 & 0.0 & 0.0 \\
\hline 2 & 1 & 1.72 & 3.43 & 0.45 & $2.0 \%$ & $1.0 \%$ \\
\hline 3 & 1 & 1.72 & 3.43 & 0.45 & $2.0 \%$ & $\%$ \\
\hline
\end{tabular}

Table(2): Physical properties of sand and gravel.

\begin{tabular}{|c|c|c|}
\hline Property & Test results for sand & Test results for gravel \\
\hline Specific weight & 2.65 & 2.65 \\
\hline Volume weight $(\mathrm{t} \mid \mathrm{m} 3)$ & 1.65 & 1.66 \\
\hline Fineness modulus & 2.85 & $1.0 \%$ by weight \\
\hline \% of fine materials & $1.0 \%$ by weight & $0.9 \%$ by weight \\
\hline Crushing value & - & $16 \%$ \\
\hline Voids ratio & $34 \%$ & $37.3 \%$ \\
\hline
\end{tabular}

Table (3). Properties of the used O. P. C.

\begin{tabular}{|c|c|c|}
\hline Mechanical properties & Test results & E.S.S limits \\
\hline Specific gravity & 3.15 & 3.15 \\
\hline Fineness \% & $6.2 \%$ & Max 10\% \\
\hline Specific surface cm2/gr. & 3975 & Min 2500 \\
\hline Water demand \% & 26 & Min 25, max 30 \\
\hline Initial setting time (minute) & 140 & Min 45 min. \\
\hline Final setting time (minute) & 400 & Max $10 \mathrm{hr}$. \\
\hline Soundness (mm) & $1.0 \mathrm{~mm}$ & Max $10 \mathrm{~mm}$ \\
\hline Compressive strength & & \\
At 3 days Kg/cm2 & 280 & Min $180 \mathrm{Kg} / \mathrm{cm} 2$ \\
At 7 days Kg/cm2 & 300 & Min $270 \mathrm{Kg} / \mathrm{cm} 2$ \\
\hline
\end{tabular}

The second category was designed to study the effect of the corrosion protection strategy adopted in this research on bond strength by means of conducting pull out test to the steel bars imbedded in the concrete cylinders. The reinforcing bars were cleaned properly by the previously mentioned method. The average diameter of the bars was accurately measured. Three bars were coated with Kemapoxy 131 and another three were coated with Epoxy celler then, immediately placed in the casting mould and filled with concrete of mix No2. Another six cleaned bars were placed in the casting mould without coating, three of them filled with concrete mix No. 1 and the others with concrete mix No.3. The details of the three concrete mixes are given in Table (1). 


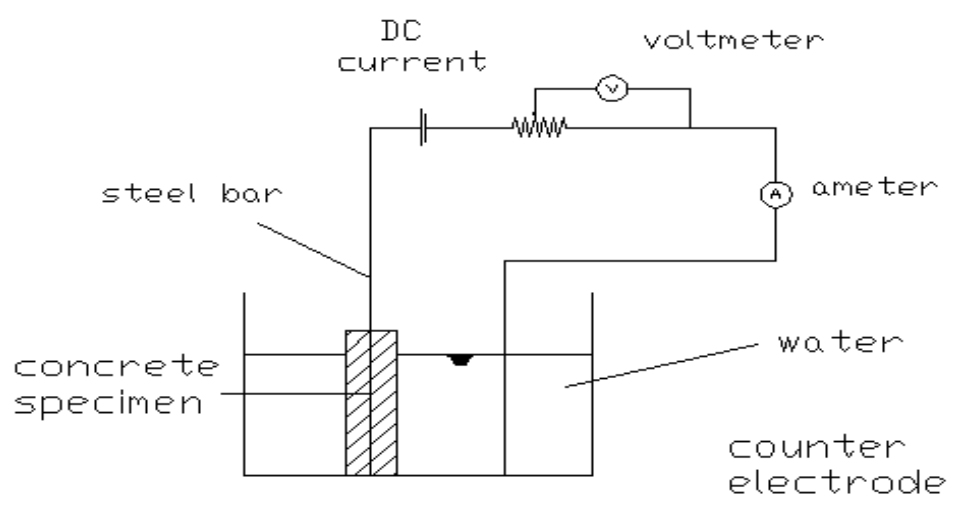

Figure (1) The electric circuit used to accelerate corrosion of steel bars.

The third category contains four reinforced concrete beams made of the previous mixes and tested under flexure. Three of them were protected from corrosion by using the three previous techniques to study the effect of corrosion protection methods on the behavior of reinforced concrete beams. The details of those beams are shown in table (4) and their reinforcement is shown in figure (2).

Table (4): Details of used concrete mixes in casting all beams.

\begin{tabular}{|c|c|c|c|c|c|c|c|c|}
\hline \multirow{2}{*}{$\begin{array}{l}\text { Beam } \\
\text { No. }\end{array}$} & \multirow{2}{*}{$\begin{array}{l}\text { Mix } \\
\text { No. }\end{array}$} & \multicolumn{4}{|c|}{ Mix Prportions } & \multirow{2}{*}{$\begin{array}{l}\% \mathrm{CaCl} 2 \\
\text { by weight } \\
\text { of cement }\end{array}$} & \multirow{2}{*}{$\begin{array}{l}\% \text { NaNO2 } \\
\text { by weight } \\
\text { of cement }\end{array}$} & \multirow[t]{2}{*}{ Epoxy Coating } \\
\hline & & 1 & $\mathrm{n}$ & $\mathrm{m}$ & $\mathrm{w} / \mathrm{c}$ & & & \\
\hline 1 & 2 & 1 & 1.78 & 3.57 & 0.45 & 2.0 & 0.0 & --- \\
\hline 2 & 3 & 1 & 1.78 & 3.57 & 0.45 & 2.0 & 1.0 & --- \\
\hline 3 & 2 & 1 & 1.78 & 3.57 & 0.45 & 2.0 & 0.0 & Epoxy celler \\
\hline 4 & 2 & 1 & 1.78 & 3.57 & 0.45 & 2.0 & 0.0 & $\begin{array}{c}\text { Kemapoxy } \\
131\end{array}$ \\
\hline
\end{tabular}
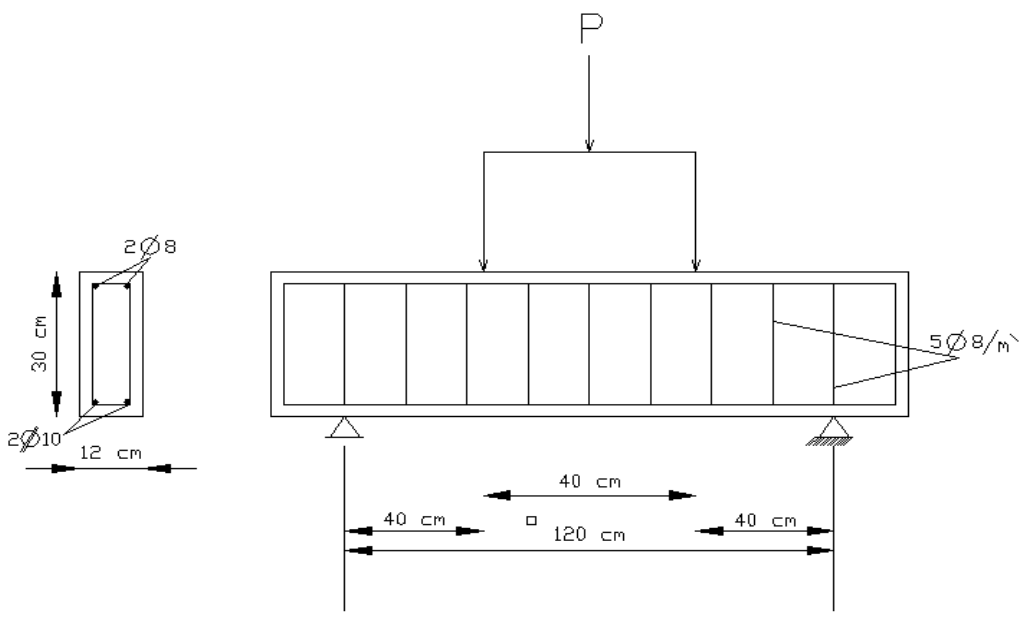

Figure (2) Reinforced concrete beam. 
All beams were stripped off 24 hours after casting then curing process was started. All the four beams were kept in the laboratory temperature and sprayed with water every day until the day before testing at age of 28 days. After that, they were put in an electric circuit as shown in fig (3) under a constant voltage of $12 \mathrm{~V}$ for fourteen days. In all beams, six rows of demec studs were stuck around the vertical axis of beams on one side of beam. Each row consists of two demec studs apart. During testing, strains of concrete were determined at each load increment using a dial gauge.

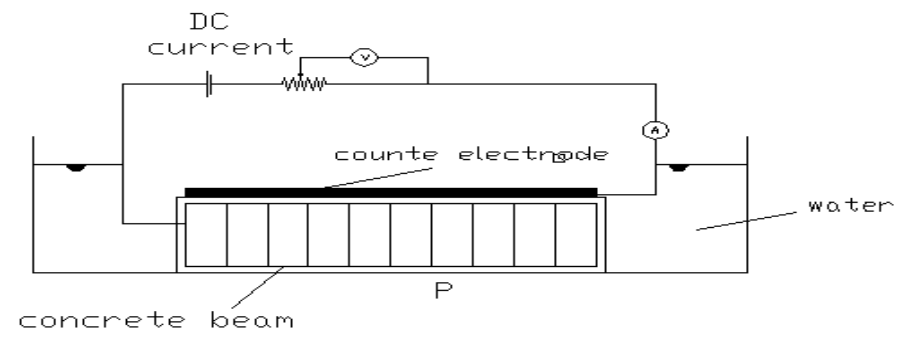

Figure (3) The electric circuit used to induce an obvious corrosion in beams.

Every beam was tested under two points static load by using digital Universal Testing Machine of capacity 10 ton. A dial gauge has an accuracy of $0.01 \mathrm{~mm}$ was used to measure the values of deflection. The applied load was increased gradually by 0.5 ton. Each increment was maintained for few minutes till recording the strains of concrete and deflection. The cracks and their propagations were marked on both beam sides and then sketched.

\section{TEST RESULTS AND DISCUSSION}

The compressive strength results obtained from testing concrete cubic specimens at different ages are plotted in figure (4). The obtained results confirm the known fact of adding calcium chloride to concrete mixes in order to improve the compressive strength of concrete, (strength-age relationship).

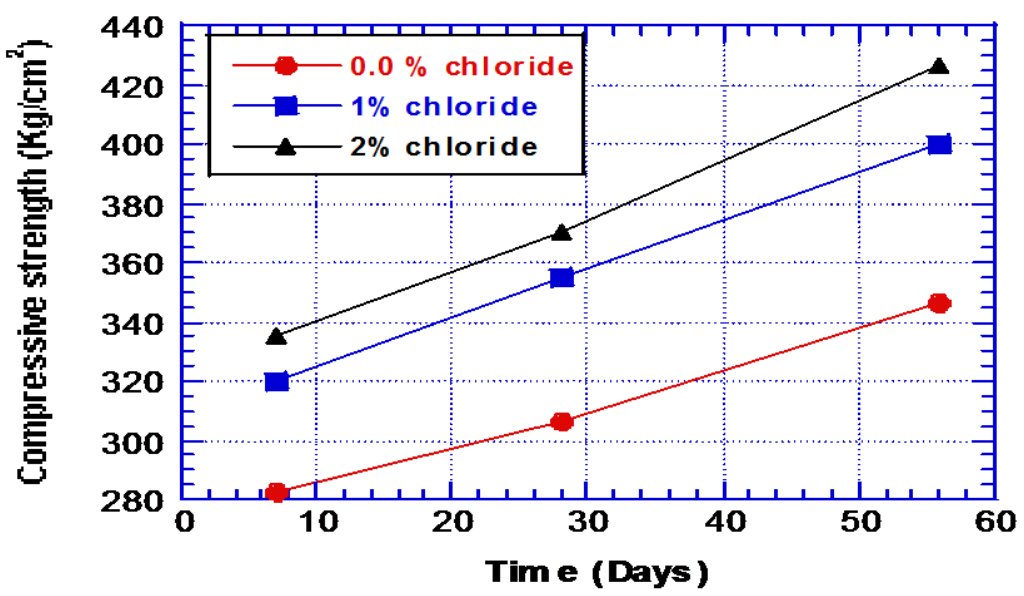

Fig. (4) Relationship between compressive strength and time for concrete mixes. 
Table (5) includes the average diameter of steel bars before and after exposing them to electric circuit for different periods of time. It also includes the percentage of reduction in the area of these bars after inducing the corrosion.

The crack widths occurred in the concrete cylinders as a result of inducing the corrosion has been measured using an accurate microscope with sensitivity of 0.01 $\mathrm{mm}$. The measured values of crack widths for the three tested groups after 1, 2, 3, 4, 6, 8 and 14 days have been recorded in table (6).

From table (5), it can be noticed that, as the period of exposing steel bars to electric energy (200 m.A.) increases, the cross-sectional area of steel bars decrease. It can be also be resulted that, the \% reduction in the cross-sectional area of the steel bars after 8 days of electric exposing produces about $11-14 \%$ reduction meanwhile, at 14 days of exposure the average values of the reduction in diameter increase to $13-17 \%$ i.e., the higher the $\%$ of added calcium chloride, the higher the $\%$ reduction in the area of steel bars.

Table (5): Reduction in the area of steel bars for all tested specimens.

\begin{tabular}{|c|c|c|c|c|}
\hline $\begin{array}{c}\text { Period of electric } \\
\text { exposure } \\
\text { (days) }\end{array}$ & $\begin{array}{c}\text { \% of chloride } \\
\text { in concrete } \\
\text { mix }\end{array}$ & $\begin{array}{c}\text { Average } \\
\text { original } \\
\text { diameter mm }\end{array}$ & $\begin{array}{c}\text { Reduction in } \\
\text { diameter mm }\end{array}$ & $\begin{array}{c}\text { \% reduction in } \\
\text { the area } \\
\text { of bars }\end{array}$ \\
\hline 0.0 & 0.0 & 9.56 & 0.00 & 0.000 \\
\hline 1 & 0.0 & 9.55 & 0.23 & 4.759 \\
\hline 2 & 0.0 & 9.53 & 0.34 & 7.008 \\
\hline 4 & 0.0 & 9.56 & 0.41 & 8.393 \\
\hline 6 & 0.0 & 9.44 & 0.46 & 9.508 \\
\hline 8 & 0.0 & 9.37 & 0.53 & 10.993 \\
\hline 14 & 0.0 & 9.60 & 0.64 & 12.889 \\
\hline 0.0 & 1.0 & 9.85 & 0.15 & 3.022 \\
\hline 1 & 1.0 & 9.68 & 0.32 & 6.502 \\
\hline 2 & 1.0 & 9.66 & 0.34 & 6.915 \\
\hline 4 & 1.0 & 9.55 & 0.45 & 9.202 \\
\hline 6 & 1.0 & 9.44 & 0.56 & 11.512 \\
\hline 8 & 1.0 & 9.39 & 0.61 & 12.570 \\
\hline 14 & 1.0 & 9.54 & 0.72 & 14.524 \\
\hline 0.0 & 2.0 & 9.63 & 0.37 & 7.537 \\
\hline 1 & 2.0 & 9.47 & 0.41 & 8.269 \\
\hline 2 & 2.0 & 9.54 & 0.46 & 9.411 \\
\hline 4 & 2.0 & 9.48 & 0.52 & 10.670 \\
\hline 6 & 2.0 & 9.45 & 0.59 & 12.097 \\
\hline 8 & 2.0 & 9.35 & 0.67 & 13.818 \\
\hline 14 & 2.0 & 9.43 & 0.82 & 16.721 \\
\hline & & & & \\
\hline & & & & \\
\hline
\end{tabular}

Table (6) comprises the test results of the crack widths occurred in the cylinders for the three tested groups after 1, 2, 3, 4, 6, 8 and 14 days. As the period of exposing steel bars to electric energy increases, the width of cracks increases too. 
A comparative study was made between the \% reduction in the area of steel bars and the corresponding crack widths for a period of ten days. This study resulted that,

- At (4 - 14) days of exposing steel bars, embedded in the control mix, the value of the $\%$ reduction in the area of steel bars equals to $8.4-13 \%$ accompanied with a crack width ranging between 0.0 to $0.73 \mathrm{~mm}$.

- At (4 - 14) days of exposing the steel bars, embedded in $1 \%$ calcium chloride concrete mix, the average $\%$ reduction in the area of steel bars equals to $9.2-14.5$ $\%$ accompanied with a crack width ranging between $0.64-0.96 \mathrm{~mm}$.

- At (4 - 14) days of exposing the steel bars, embedded in $2 \%$ calcium chloride concrete mix, the value of $\%$ reduction of steel area equal to $10.7-16.7 \%$ accompanied with a crack width ranging between $0.68-1.0 \mathrm{~mm}$.

Table (6): Crack widths in cylinderical concrete specimens due to corrosion of steel bars.

\begin{tabular}{|c|c|c|c|c|c|c|c|}
\hline $\begin{array}{c}\text { Period of } \\
\text { electric } \\
\text { exposiure } \\
\text { (days) }\end{array}$ & $\begin{array}{c}\text { \% of } \\
\text { chloride } \\
\text { in } \\
\text { concrete } \\
\text { mix }\end{array}$ & $\begin{array}{c}\text { Crack } \\
\text { width } \\
(\mathrm{mm})\end{array}$ & $\begin{array}{c}\text { Crack } \\
\text { width } \\
2 \\
(\mathrm{~mm})\end{array}$ & $\begin{array}{c}\text { Crack } \\
\text { width } \\
3 \\
(\mathrm{~mm})\end{array}$ & $\begin{array}{c}\text { Crack } \\
\text { width } \\
4 \\
(\mathrm{~mm})\end{array}$ & $\begin{array}{c}\text { Crack } \\
\text { width } \\
5 \\
(\mathrm{~mm})\end{array}$ & $\begin{array}{c}\text { Average } \\
\text { Crack } \\
\text { width } \\
(\mathrm{mm})\end{array}$ \\
\hline 0.0 & 0.0 & 0.0 & 0.0 & 0.0 & 0.0 & 0.0 & 0.0 \\
\hline 1 & 0.0 & 0.0 & 0.0 & 0.0 & 0.0 & 0.0 & 0.0 \\
\hline 2 & 0.0 & 0.0 & 0.0 & 0.0 & 0.0 & 0.0 & 0.0 \\
\hline 4 & 0.0 & 0.0 & 0.0 & 0.0 & 0.0 & 0.0 & 0.0 \\
\hline 6 & 0.0 & 0.5 & 0.6 & 0.4 & 0.5 & 0.8 & 0.56 \\
\hline 8 & 0.0 & 1.2 & 1.0 & 0.4 & 0.5 & 0.3 & 0.68 \\
\hline 14 & 0.0 & 1.2 & 1.1 & 0.6 & 0.7 & 0.5 & 0.73 \\
\hline 0.0 & 1.0 & 0.0 & 0.0 & 0.0 & 0.0 & 0.0 & 0.0 \\
\hline 1 & 1.0 & 0.06 & 0.1 & 0.1 & 0.12 & 0.1 & 0.096 \\
\hline 2 & 1.0 & 0.2 & 0.2 & 0.18 & 0.3 & 0.15 & 0.2 \\
\hline 4 & 1.0 & 0.6 & 0.4 & 1.0 & 0.8 & 0.4 & 0.64 \\
\hline 6 & 1.0 & 1.0 & 0.4 & 0.4 & 0.8 & 1.0 & 0.72 \\
\hline 8 & 1.0 & 1.3 & 1.0 & 0.4 & 0.8 & 0.6 & 0.82 \\
\hline 14 & 1.0 & 1.5 & 1.1 & 0.5 & 0.8 & 0.9 & 0.96 \\
\hline 0.0 & 2.0 & 0.0 & 0.0 & 0.0 & 0.0 & 0.0 & 0.0 \\
\hline 1 & 2.0 & 0.1 & 0.08 & 0.15 & 0.1 & 0.2 & 0.13 \\
\hline 2 & 2.0 & 0.25 & 0.2 & 0.18 & 0.3 & 0.25 & 0.24 \\
\hline 4 & 2.0 & 0.6 & 0.6 & 0.8 & 0.8 & 0.6 & 0.68 \\
\hline 6 & 2.0 & 1.4 & 0.6 & 1.2 & 1.2 & 1.0 & 0.81 \\
\hline 8 & 2.0 & 0.6 & 0.6 & 0.8 & 1.6 & 0.8 & 0.88 \\
\hline 14 & 2.0 & 0.8 & 0.7 & 0.8 & 1.4 & 1.3 & 1.0 \\
\hline & & & & & & & \\
\hline
\end{tabular}

The pull-out test results of the concrete cylinders are indicated in table (7). The average bond strength as well as the \% reduction in the area of the steel bars are also included in this table. The relationship between the average bond strength values and 
the period of exposing the concrete mixes to the electric current (DC) for the different $\%$ of chloride is illustrated in figure (5).

It can be noticed that, as the period of electric exposure increases the corrosion rate increases accompanied by a reduction in the bond strength. This can be explained as follows; the corrosion of steel produces both iron oxide and hydroxide having a greater volume than the volume of the original steel bar which leads to increase in the volume of steel bars causing high radial bursting stresses particularly around the reinforcing bars and finally local radial cracks occurred. These splitting cracks propagate along the bar formatting longitudinal cracks and consequently led to a reduction in bond strength see-table (7).

Table (7): Bond strength results of concrete cylinders.

\begin{tabular}{|c|c|c|c|c|}
\hline $\begin{array}{c}\text { Period of electric } \\
\text { exposing (days) }\end{array}$ & $\begin{array}{l}\% \text { of chloride by } \\
\text { weight of cement }\end{array}$ & $\begin{array}{l}\text { Pull-out } \\
\text { Load }\end{array}$ & Bond stregth & $\begin{array}{c}\% \text { reduction } \\
\text { of area bar }\end{array}$ \\
\hline 0.0 & 0.0 & 1.91 & 33.776 & 0.000 \\
\hline 1.0 & 0.0 & 1.56 & 27.587 & 4.759 \\
\hline 2.0 & 0.0 & 1.55 & 27.410 & 7.008 \\
\hline 4.0 & 0.0 & 1.51 & 26.703 & 8.393 \\
\hline 6.0 & 0.0 & 1.37 & 24.227 & 9.508 \\
\hline 8.0 & 0.0 & 0.65 & 11.495 & 10.993 \\
\hline 14 & 0.0 & 0.60 & 10.61 & 12.889 \\
\hline 0.0 & 1.0 & 1.8 & 31.831 & 3.022 \\
\hline 1.0 & 1.0 & 1.44 & 25.465 & 6.502 \\
\hline 2.0 & 1.0 & 1.39 & 24.806 & 6.915 \\
\hline 4.0 & 1.0 & 0.99 & 17.507 & 9.202 \\
\hline 6.0 & 1.0 & 0.66 & 11.671 & 11.512 \\
\hline 8.0 & 1.0 & 0.3 & 5.305 & 12.570 \\
\hline 14 & 1.0 & 0.27 & 4.7746 & 14.524 \\
\hline 0.0 & 2.0 & 1.66 & 29.335 & 7.537 \\
\hline 1.0 & 2.0 & 1.36 & 24.050 & 8.269 \\
\hline 2.0 & 2.0 & 1.26 & 22.282 & 9.411 \\
\hline 4.0 & 2.0 & 0.79 & 13.970 & 10.670 \\
\hline 6.0 & 2.0 & 0.37 & 6.543 & 12.097 \\
\hline 8.0 & 2.0 & 0.32 & 5.659 & 13.818 \\
\hline 14 & 2.0 & 0.26 & 4.598 & 16.721 \\
\hline
\end{tabular}

The three protection methods employed in this research were applied to reinforced concrete beams as well as identical concrete cylinders with embedded reinforcing bars to study the effect of applying these protection methods on the bond strength and the mechanical performance of reinforced concrete beams. A control beam and cylinders fabricated from the same mix without any protection method were casted and tested for the purpose of comparison. 


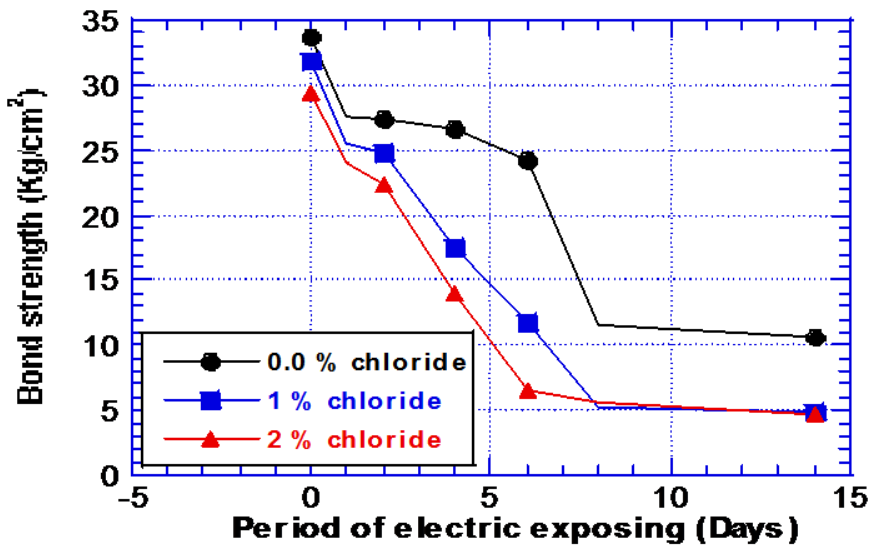

Fig (5) Relationship between bond strength and the periods of electric current exposure.

The effect of applying the used anti-corrosive materials on the bond strength is indicted in table (8) and plotted in fig (6). The values of bond strength resulted from the protected specimens were as three times as the value of the bond strength recorded from the control one. The bond strength increased from $4.6 \mathrm{~kg} / \mathrm{cm} 2$ to about 12 $\mathrm{kg} / \mathrm{cm} 2$.

From the following table (8) and Fig (6), it can be noticed that, adding $1 \%$ of sodium nitrite to the concrete cylinders produced an improvement in the pull-out load with a value of $315 \%$. Meanwhile, applying an epoxy coating material to steel bars resulted an increase in the pull-out load by a value of $265 \%$ and $246 \%$ when using Epoxy celler and Kemapoxy 131 respectively.

Table (8): Bond strength results of specimens protected by using anticorrosive materials.

\begin{tabular}{|c|c|c|c|c|c|}
\hline $\begin{array}{c}\text { Mix } \\
\text { No. }\end{array}$ & $\begin{array}{c}\text { Method of } \\
\text { protection }\end{array}$ & $\begin{array}{c}\text { Period of } \\
\text { electric } \\
\text { exposure (days) }\end{array}$ & $\begin{array}{c}\text { Pull-out } \\
\text { Load } \\
\text { (tons) }\end{array}$ & $\begin{array}{c}\text { Bond } \\
\text { stregth } \\
(\mathrm{Kg} / \mathrm{cm} \\
2)\end{array}$ & $\begin{array}{c}\% \text { reduction in } \\
\text { the area of the } \\
\text { bar }\end{array}$ \\
\hline M1 & Control & 14 & 0.26 & 4.598 & 16.72 \\
\hline M2 & 1\% sodium nitite & 14 & 0.82 & 14.5 & 8.81 \\
\hline M3 & $\begin{array}{c}\text { Coating with } \\
\text { Epoxy celler }\end{array}$ & 14 & 0.69 & 12.19 & 9.56 \\
\hline M4 & $\begin{array}{c}\text { Coating with } \\
\text { Kemapoxy 131 }\end{array}$ & 14 & 0.64 & 11.31 & 10.79 \\
\hline
\end{tabular}

Figure (7) shows the relationship between the load and the corresponding deflection for the reinforced concrete beams tested under bending. As the load increases the corresponding deflection increases up to failure. The maximum deflection, measured at 0.9 of the ultimate load, was found to be $2.0 \mathrm{~mm}$ with slight differences between each others. 


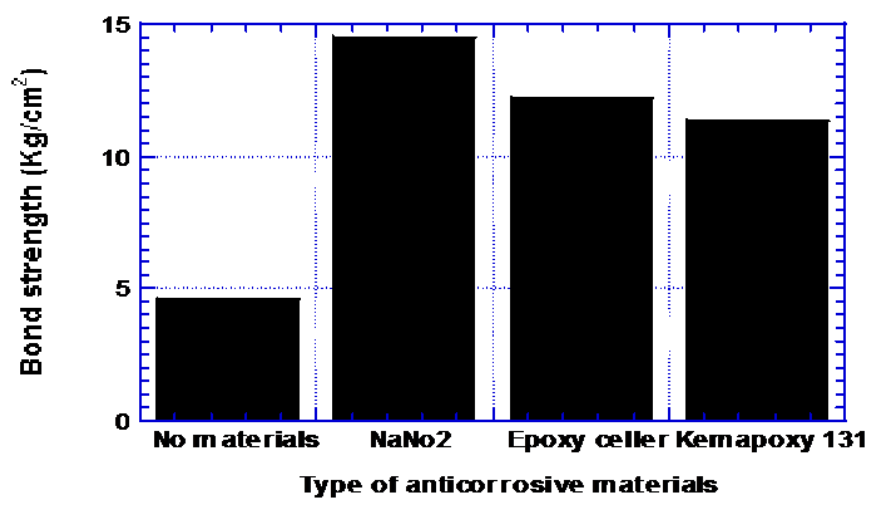

Fig (6) Relationship between bond strength and type of anticorrosive materials.

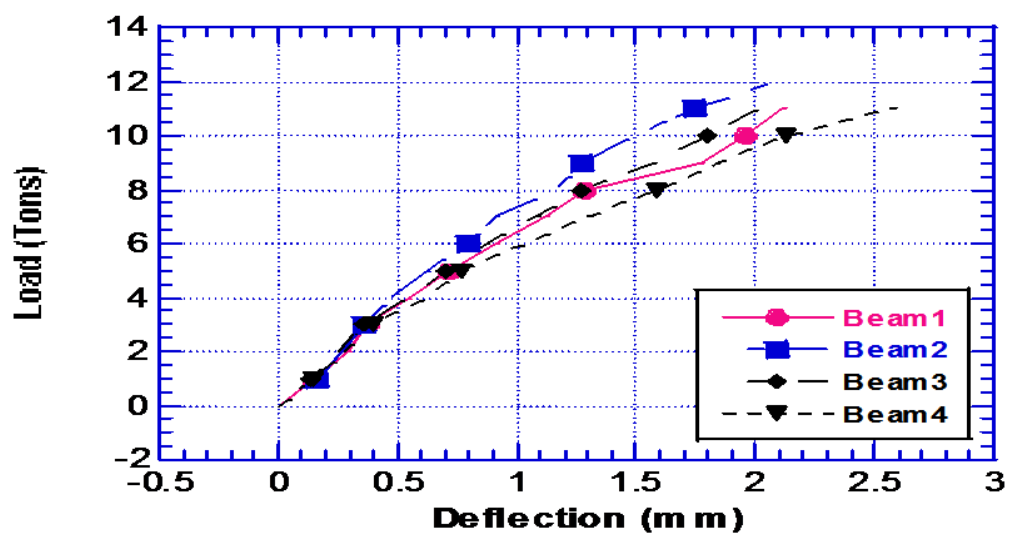

Fig (7) Relationship between load and deflection for all tested beam.

It can be recommended that, the economic anticorrosive coating material is the epoxy celler when compared with the kemapoxy 131 . The sodium nitrite is the best anti-corrosive protecting material although, it is expensive as well as the hazards of using it in the explosive products.

The cracking load was recorded for all tested beams at which the first visible crack occurred. There was no difference in the recorded cracking load of beams B1, B2 and B3 and equals to 4.0 tons. Beam (B4) which contains kemapoxy 131 coating produced 5.0 tons cracking load. The ultimate loads for tested beams were also recorded at which the failure occurred. Beam (B2) contains $1 \%$ sodium nitrite as an additive resisted up to 13.60 tons failure load. The lowest value of ultimate load was 11.8 tons and resulted from testing the control beam (B1) which made without anticorrosive material.

Figures 8, 9,10 and 11 represent the pattern of cracks in the three sides of each beam [front (A), back(C) and bottom (B)], the reason of representing the cracks in three faces is to show the extension of the cracks through them. It can be noticed that cracks firstly happened in the region of maximum deflection under the load effect and 
then spread all over the beam ended by a shear type of failure, except for beam (B2) a shear bond failure happened at the final stage of load ( just before failure occurred ).

The general mode of failure for all tested beams was found to be shear failure that is mainly because the ratio between shear span and depth $(\mathrm{a} / \mathrm{d})=1.45$.

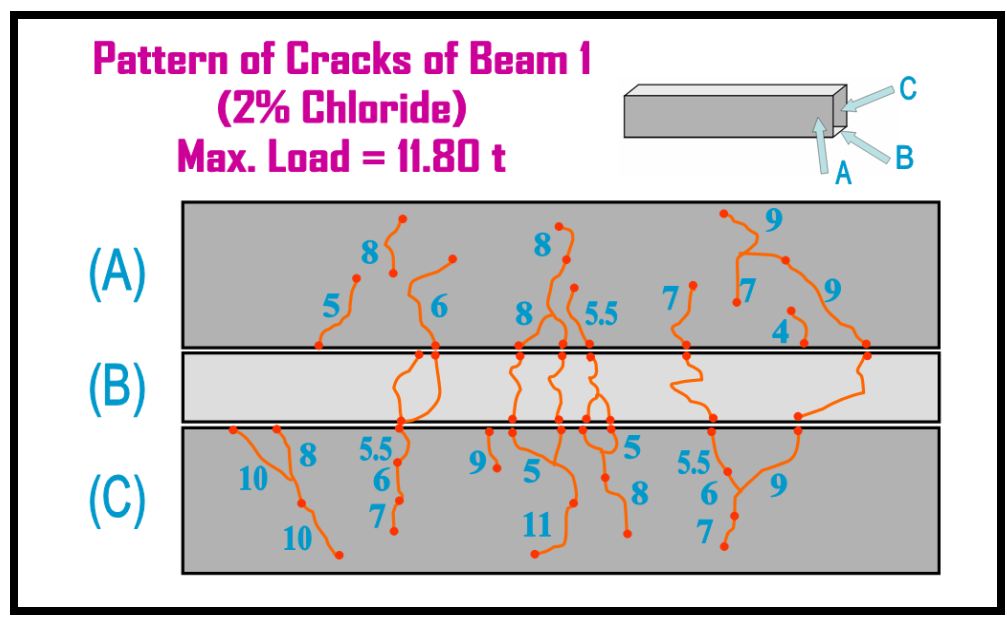

Figure (8) Pattern of cracks of beam (1)

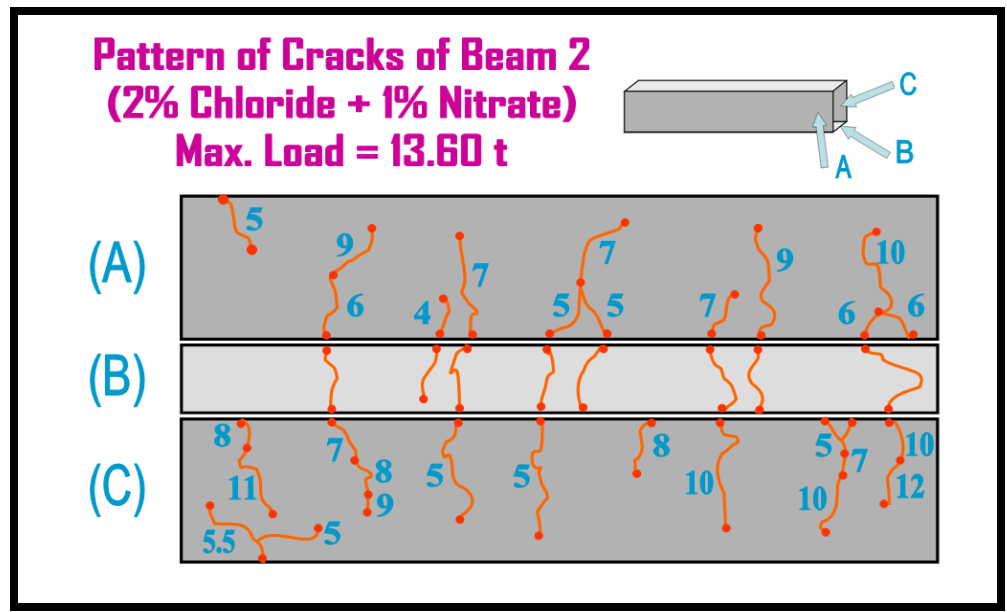

Figure (9) Pattern of cracks of beam (2).

The cracking and ultimate experimental loads for the four tested beams were recorded in the following table (9). From this table, it can be seen that, adding $1 \%$ sodium nitrite to concrete mix as a corrosion protective material improves the ultimate load by a value of $15 \%$, meanwhile, coating steel reinforcing bars only increases the ultimate load by a value of 2-6\%. The ratio between cracking and ultimate loads ( Pcr / Pult ) was found to be in the range of $0.29-0.33$ for beams (B1, B2, \&B3) however, beam (B4) resulted a ratio of 0.42 which may explains the effectiveness of using epoxy coating as a protective material against corrosion. The highest value of flexural strength was resulted from testing beam (B2) with $1 \%$ sodium nitrite and equals to 151 $\mathrm{Kg} / \mathrm{cm}^{2}$. 
Pattern of Cracks of Beam 3

(2\% Chlaride + Epaxy Celler)

Max. Laad = 12.50 t

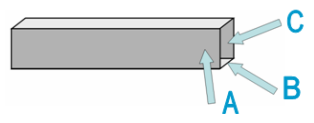

(A)

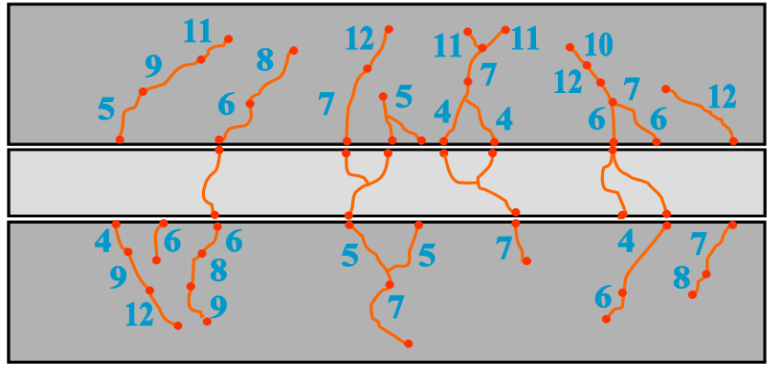

Figure (10) Pattern of cracks of beam (3).

Cracks Profile of Beam 4

(2\% Chloride + Kemapaxy)

Max. Load = 12.01 t

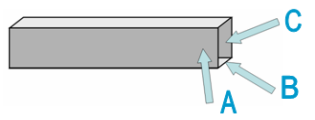

(A)

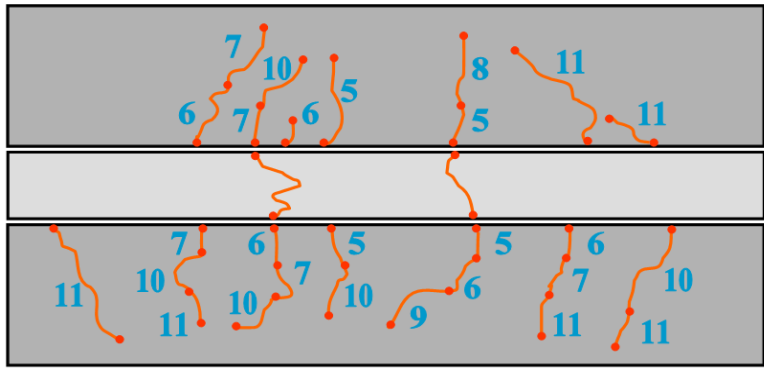

Figure (11) Pattern of cracks of beam (4).

Table (9): Test results of R.C. beams.

\begin{tabular}{|c|c|c|c|}
\hline Beam No. & Pcr (tons) & Pult (tons) & Flexural stregth $\left(\mathrm{Kg} / \mathrm{cm}^{2}\right)$ \\
\hline B1 & 4.0 & 11.8 & 131.11 \\
\hline B2 & 4.0 & 13.6 & 151.11 \\
\hline B3 & 4.0 & 12.5 & 138.44 \\
\hline B4 & 5.0 & 12.0 & 133.44 \\
\hline
\end{tabular}

\section{CONCLUSIONS}

Based on the present study, the following conclusions, with respect to the effect of the used different methods to protect the reinforcing steel bars from corrosion, are drawn:

1 . The higher the $\%$ of added calcium chloride, the higher the $\%$ reduction in the area of steel bars. 
2. As the period of exposing steel bars to electric circuit ( DC current) increases, the width of crack increases too.

3. As the period of exposing steel bars to electric energy increases, the necessary load to pull the steel bars out from concrete decreases, that is because exposing steel bars to electric energy for long time increases the induced corrosion then the value of pull-out load decreases. Also it has been found that, as the period of exposing steel bars to electric energy increases, the value of bond strength decreases accompanied by increasing the \% reduction of area of steel bars.

4. Adding $1 \%$ of sodium nitrite to the concrete cylinders showed an improvement in pull-out load by value of $300 \%$. The highest value of flexural strength was resulted from the beam made of this mix.

5. Sodium nitrite showed the best result as an anticorrosive material in the reinforced concrete beams tested in flexure. The addition of $1 \%$ of it, increases the ultimate load by a value of $15 \%$, meanwhile coating steel reinforcing bars only increases the ultimate load by a value of $(2-6 \%)$.

6. The economic anticorrosive coating material is found to be the epoxy celler when compared with the kemapoxy 131. Sodium nitrite is the optimum anti-corrosive additive material but, the hazards of using it in the explosive products as well as being it an expensive make its usage is difficult.

\section{REFERENCES}

1. Hamad, B. S., "Comparative bond strength of coated and uncoated bars with different rib geometries", ACI, Materials J., Vol. 92, No. 6, Nov. - Dec. 1995, pp. 579-589.

2. Ghaffari, H. A., Choi, O. C., Darwin, D. and Mccabe, S. L., "Bond of epoxy coated reinforcement: cover, casting position, slump and consolidation", ACI, struc. J., Vol. 91, No. 1, Jan. - Feb. 1994, pp. 59-68.

3. Yehia, N. A., "Experimental study of bond between concrete and reinforcing steel bars coated for corrosion protection", Journal of Eng. And applied science., Vol. 42, No. 4, Aug. 1995, Cairo University, Egypt.

4. Rasheeduzzafar, Ali M. G. and Al-Sulaimani, G. J., "Degradation of bond between reinforcing steel and concrete due to cathodic protection current ", ACI, Materials J., Vol. 90, No. 1, Jan. - Feb. 1993, pp. 8-15.

5. Berke, Neal S., Dallaire, M. P., Kicks, M. C., and Hoopes, R. J. (1993). "Corrosion of Steel in Cracked Concrete," Corrosion Engineering, Vol. 49, No. 11, Nov., pp.934-943.

6. Berke, Neal S. and Rosenberg, Arnold. (1989). "Technical Review of Calcium Nitrite Corrosion Inhibitor in Concrete," Transportation Research Record, No. 1211, pp. 18-27.

7. Virmani, Yash Paul and Clemena, Gerardo G. (1998). "Corrosion ProtectionConcrete Bridges," Report No. FHWA-RD-98-088, Federal Highway Administration, Washington, D.C.

8. Berke, Neal S., Pfeifer, Donald W., and Weil, Thomas G. (1988). "Protection Against Chloride-Induced Corrosion," Concrete International, Vol. 10, No. 12, Dec., pp. 45-55. 
9. Nmai, Charles K., Farrington, Stephen A., and Bobrowske, Gregory S. (1992). "Organic-Based Corrosion-Inhibiting Admixture for Reinforced Concrete," Concrete International, Vol. 14, No. 4, Apr., pp. 45-51.

10.Clear, Kenneth C. (1992). "Effectiveness of Epoxy-Coated Reinforcing Steel," Concrete International, Vol. 14, No. 5, May, pp. 58-64.

11.Manning, David G. (1996). "Corrosion Performance of Epoxy-Coated Reinforcing Steel: North American Experience," Construction and Building Materials, Vol. 10, No. 5, Jul. pp. 349-365.

\section{دراسة معملية لحماية أسياخ حديد التسليح من الصدأ}

من أهم المشاكل التى تواجه المنشآت الخرسانية المسلحة هى صدأ الحديد داخل عناصر هذه

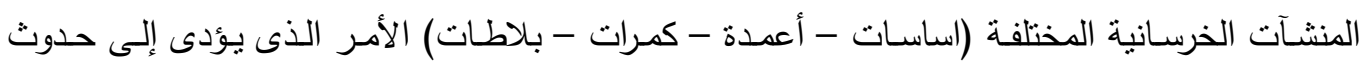

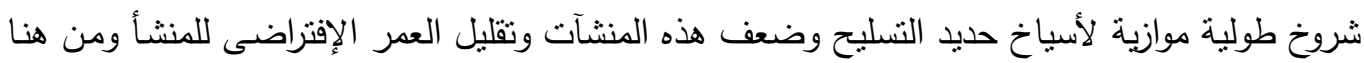
نشأت فكرة حماية حديد النسليح من الصدأ. الغرض الأساسى من هذا البحث هو نطبيق ثنلاث طرق مختلفة لحماية حديد النسليح من حدوث الصدأ

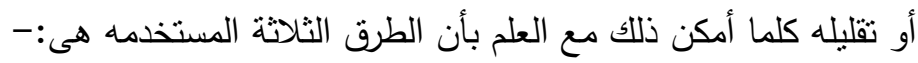
1. دهان حديد التسليح بمادة كيمابوكسى 131 2. دهان حديد التسليح بمادة إييوكسى سيلير حلئ 3. إضافة مادة نتريت الصوديوم بنسبة 1 \% من وزن الأسمنت وإذابته فى ماء الخلط (وإستخدامه كمثبط لصدأ الحديد)

وينقسم البرنامج العملى إلى ثلاثة مجموعات. المجموعة الأولى تثمل صب 54 أسطوانة من الخرسانة

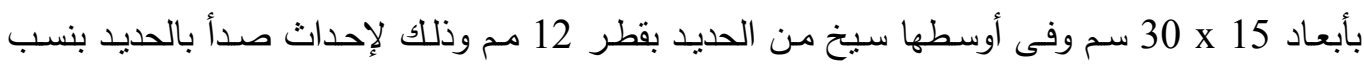
مختلفة وذلك بإستخدام دائرة كهربية بتيار مستمر وبفرق جهد 12 فولت ثم قياس معدل الصدأ فى كل سيخ من كل أسطوانة على حدة وذلك بقياس النقص فى مساحة مقطع السيخ عند عشرة مواضع مختلفة من السيخ ثم حساب منتسط النقص فى مساحة المقطع لكل ثلاثة اسياخ لها نفس الخلطة الخرسانية بعد فئح مرور زمن معين ثابت تحت ثأثثر التيار الكهربى المستمر وذلك بعد إجراء إختبار الإقتلاع لمعرفة مدى تأثثر إجهاد التماسك بين الحديد والخرسانة بمعدل صدأ لحديد التسليح. أما المجموعة الثانية فتشمل 12

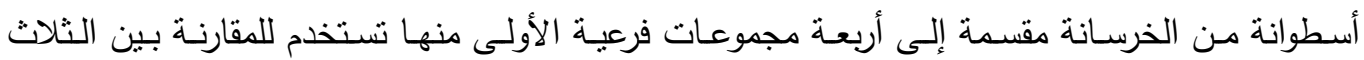

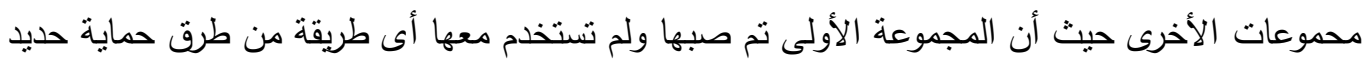
النسليح المنسخدمة من الصدأ أما الثانية تم دهان حديد النسليح بمادة كيمابوكسى 131 والثالثة تم دهات دهان الحديد بمادة أيبوكس سيلير قبل عملية الصب والأخيرة تم أستخدام مادة نيتريت الصوديوم مع ماء خلط بلط 
الخرسانة كمثبط لعملية الصدأ وجميع الأسطوانات الأثثى عشر نم وضعها فى الدائرة الكهربية المستخدمة

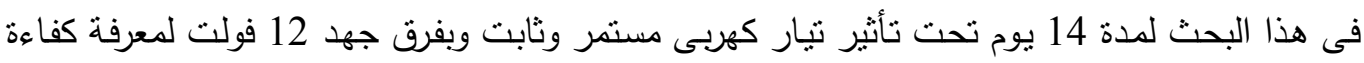

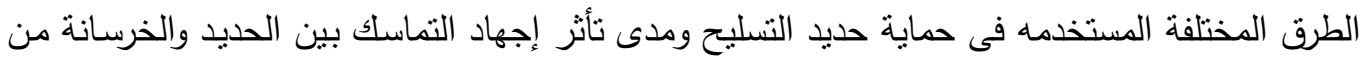

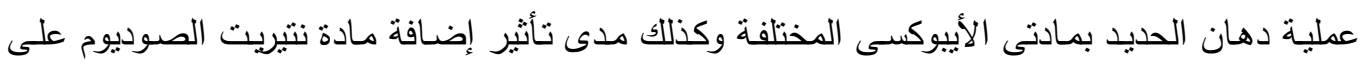

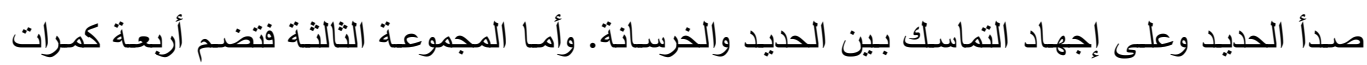
خرسانبة مسلحة لها نفس التسليح ونفس الأبعاد ونفس رتبة الخرسانة وتخلتف فقط فى طريقة حماية حديد

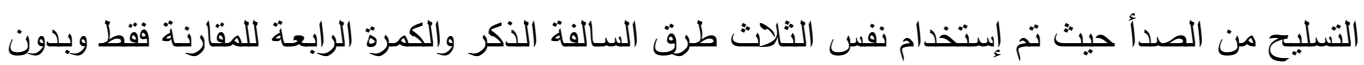

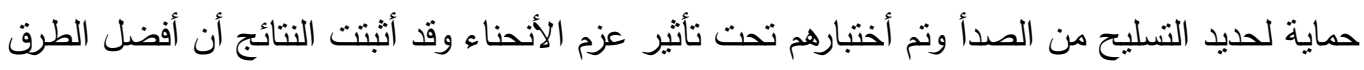

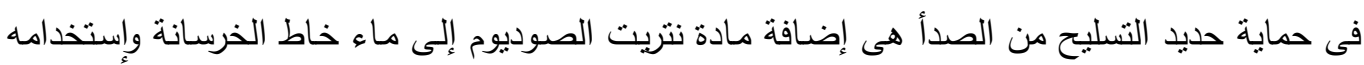
كمثبط لعملية الصدأ بينما تأتى عملية دهان الحديد بمادة اييوكسى سيلير أفضل من دهان الحديد الحيد بمادة كيمابوكسى 131 وذللك لحمايته من الصدأ. 